\title{
THE LIMITS OF CORPORATE CHAINS AND BRAND MANAGEMENT: "Loyalty" and the Efficacy of Vernacular Markets in the Andes
}

\author{
JULIANE MÜLLER \\ University of Munich \\ (iD) https:/ / orcid.org/0000-0003-2126-6521
}

Walking through the streets of La Paz, Bolivia, where the electronics wholesale and retail trade is concentrated - a densely populated area northwest of the city center with sidewalk sales, small retail shops, warehouses, and popular shopping galleries - one commonly sees a native trader woman talking to a representative of the South Korean firm Samsung Electronics about shelf display, or, more recently, in a conversation with an employee of the national branch of Chinese Huawei Technologies about deposits. The Bolivian employees of these East Asian multinationals are in daily contact with shopkeepers and street vendors. Through personalized attention, gifts, and bonus payments, they try to create brand fidelity among traders and convince them to collaborate with market research and inventory control. In business jargon, they deploy midstream and downstream supply-chain management to render the distribution of electronics more predictable, cost and time efficient, as well as more in line with trade and brand marketing to enhance sales at the retail end of the chain.

Although the corporations have engaged in these activities for the past fifteen years, the terms of market exchange continue to be set mainly by vendors, shopkeepers, and wholesale traders. While the labor of the corporate staff adds a more official aura to the area and makes it more attractive for middle- and up- 
per-middle-class clients, any of the most fashionable appliances continue to be available in different value classes according to price, quality, and brand authenticity. Fancy billboard advertisements for flat-screen televisions and glimmering shelves with the newest smartphones abound; but there are no price tags, as the price is produced along particularistic market channels and ultimately set during the final sales transaction.

Based on eighteen months of fieldwork (in 2013-2018 and 2020) with both corporate employees and traders, ${ }^{1}$ this article aims to make sense of the persistence of a vernacular market despite attempts to profoundly change it. By analyzing corporate strategies, technologies, and visions of the market against the backdrop of traders' economic actions and understandings, I show that the market's persistence is not a matter of traders' collective rejection of, resistance to, or moral objection to the multinationals. Retail traders agree to rearrange their shops to display brand-name products prominently and happily receive merchandising material. Yet they reject multinationals' interference when it comes to the concrete handling and pricing of products. Wholesalers are especially reluctant to disclose information on prices and stock, and they hesitate to have their products registered as inventory.

My analytical approach has been informed by this tension between corporations and traders about how to move, store, define, price, and sell the electronic appliances. The products - their circulation, classification, and valuation - demand greater attention than they usually receive in the literature on marketplace trade, street economies, and popular commerce in the global South, focused on traders' local spaces, social networks, and institutions. ${ }^{2}$ The strain I observed between traders and corporations guided me toward and made me start from the work of actor-network economic sociologists (cf. Kjellberg 2007; Çalişkan 2010; Çalişkan and Callon 2010) who critically address the knowledge practices and technological devices that lie at the heart of the economic (re)ordering of markets - namely, the requalification of goods and their rechanneling. Such a reordering of the market constitutes an ideological project often disguised in a discourse of consumer interest and economic efficiency (Kjellberg 2007).

This article explores the concept of the practical efficacy of traders' market channels and transactions in contrast to the efficiency of supply chains, homogenous pricing, and image branding as envisioned by corporate managers. In essence, practices are efficacious or effective if they deliver what they promise or aim to achieve, whereas efficient processes are further specified by the input-output relationship. ${ }^{3}$ The idea that the economy must be run efficiently because of a scar- 
city of resources lies at the basis of the discipline of economics. It is a notorious normative argument for and powerful instrument to achieve liberal market reforms. Most important for my analysis, whereas Taylorist scientific management focused on organizational and task efficiencies, contemporary chain management concerns itself with process efficiency (Witzel 2002). Maximizing the communicational, informational, and technical efficiencies of supply and distribution chains is considered a last resort for corporations looking to make big profits (Bonacich and Wilson 2008; Tsing 2009; Cowen 2010). ${ }^{4}$ This means, for example, Samsung Electronics and Huawei Technology in Bolivia try to gain market share primarily by creating predictable high demand through brand marketing and making sure the right goods reach the market at the envisioned moment, instead of competing in the production process and at the technical level.

Efficacy, in contrast, indexes effectiveness. Following Claude Lévi-Strauss's (1963) seminal essay "The Effectiveness of Symbols," the term is commonly used in relation to cosmologies and healing, and, accordingly, in medical anthropology and ritual studies. In this article, I make use of one of the essay's core ideas: market channels and arrangements (like a healing cure) might prove materially effective even though this is difficult to measure. ${ }^{5}$ The effectiveness here relies on and is distributed among the social, physical and affective infrastructures that make a market lasting, appealing, and meaningful. Efficacy offers a conceptual language to think about the productive processes and effects of markets that are complex and semiformal but are neither wasteful nor deemed to disappear. In this sense, effective market channels and arrangements are often labor intensive, offering income for large numbers of people. An effective market fulfills its purpose for the people with a stake in it, and creates an environment in which clients find a wide range of products, as well as a variety of prices and qualities to choose from. They should also be relatively attractive in terms of working conditions and income in comparison to other job opportunities. The notion of the vernacular further explicates this last point. The vernacular invites us to explore transactional forms, idioms, and relations of mutuality as well as modes of valuation and pricing that successfully nurture peoples' expectations of a "gainful margin” (Guyer 2004; Roitman 2007). Vernacular markets are self-built over time, but not necessarily free from external influences, for example, that of marketing professionals (Welker 2018). Following other ethnographic analyses of Andean mercantile forms and dynamics (Seligmann 2004; Antrosio and Colloredo-Mansfeld 2015), as well as non-state economic regulation of open-air markets and indigenous economies in South America (Thomas 2016; Dewey 2020), this article addresses tensions over market making and value 
creation at the heart of contemporary power struggles in Bolivia, the Andes, and beyond.

The encounter between actors who represent the world of grassroots trade, on the one hand, and globalization writ large, on the other, brings into focus the way that the former are increasingly targeted by mass retailers and big manufacturers looking for "emergent markets" into which to expand to increase profits. Corporations mobilize resources, technologies, the law, and discourses of authoritative knowledge to actively make and remake market arrangements, and to render things more efficient and profitable for them (Mazzarella 2003; Çalişkan and Callon 2010). Yet these actions do not make for a conflict-free process or a linear progression toward "debasement” (Gudeman 2008), nor a frictionless superimposition of a universal model onto marketplace trade. The multinationals depend on regional transport entrepreneurs, local marketers, and other commercial intermediaries, or mediators, ${ }^{6}$ to successfully move their goods, advertise them to culturally informed customers, and ensure they are adopted in retail markets worldwide (Mazzarella 2003; Foster 2007; Welker 2018). It is through such an engagement across difference that relations of domination and power work in globalized markets and supply chains (Çalişkan 2010; Tsing 2013). Electronics, as other products, undergo various processes of (re-)classification and (re-)valuation in circulation and exchange, and these alter their commodity status.

This article reiterates the importance of denaturalizing the notion of the market by revealing how different economic actors perceive, understand, act on, create, and change markets. This is a labor-intensive process neglected by dominant ideas about abstract processes and atomized actors (Applbaum 2004). Markets are made and regulated by institutions, interpersonal relationships, and mutual expectations, as well as through legal, technological and material tools that I understand here as including commercial law, knowledge practices, and the physical and sensory features that facilitate the circulation and frame the commercialization of goods - from transport and storage facilities to the arrangement of sales outlets, advertising banners, and commercials to the materiality of the products and their packages (see Welker 2018). By contrasting the vernacular and the corporate, traders' and corporate labor, I seek to contribute to an ethnographic understanding of the complexity and contingency of markets and market channels, not mainly to deconstruct ahistorical ideas and untenable assumptions but to offer a substantive understanding of the potential limits of corporate-capitalist chain and brand management. Ethnographically, it does not suffice to say that the spatial-temporal coordination of commodity chains as a network of heterogeneous actors and or- 
ganizations is unstable and creates unpredicted outcomes (cf. Gregson, Crang, and Antonopolous 2017). It is also necessary to comprehend why-both structurally and culturally.

In what follows, I first describe the electronics trade in the context of burgeoning marketplaces in urban Bolivia during the past two decades, as well as the arrival of multinational electronics companies at the heart of popular commerce in La Paz. I then analyze the labor of corporate employees, mainly those working for Samsung Electronics. Chain management, trade marketing, and brand merchandising face several challenges as traders' commitments are primarily oriented toward other market actors, not the corporations. I characterize long-term seller-buyer relationships and the expectation of mutual benefit that nurture these other commitments. The article goes on to explore an area in which corporate and traders' interests and meanings fundamentally differ, namely, the valuation and pricing of products. In the conclusion, I sum up the qualities that comprise vernacular market efficacy and discuss its wider implications for how we conceptualize commodity exchange in the current conjuncture of supply chain capitalism and corporate branding.

\section{THE ELECTRONICS TRADE IN BOLIVIA AND THE REGION}

There are about two thousand electronics traders in La Paz. ${ }^{7}$ They form part of the wider socio-commercial world of Bolivian independent traders (cuentapropistas, which means "those working on their own account"). In the macrodistrict of Max Paredes, on the northwestern slopes of La Paz, relatively close to the center and easily accessible from other parts of the city and El Alto, located above the valley of $\mathrm{La} \mathrm{Paz}$, traders of the most diverse products and commodity groups have materially upgraded street trade into enduring material structures. They have simultaneously constructed webs of commercial relations with distant partners (Tassi 2016; Müller 2018). Despite increasing internal differences in investment capital and purchasing volumes, traders usually operate as individuals, married couples, or nuclear families, supported by only a few kin and fewer than five employees. They organize through territorially defined associations. Those traders who rent or own their own shops are less actively involved in collective political action than street vendors, but they remain part of Bolivia's huge traders' unions (gremiales), organized locally, regionally, and nationally (Hummel 2017). Gremiales publicly identify as retail traders (comerciantes minoristas) and are persistently associated with the country's rampant informal economy. ${ }^{8}$ They represent about 1.5 
to 2 million people (of a total population of 11.5 million) who are, in one way or another, involved in trading and related activities. ${ }^{9}$

Whereas electronics traders share their principal organizational forms and terms of political engagement with traders of food and less expensive manufactured products such as clothes and furniture, some important particularities exist. Electronics traders have constructed commercial areas and shopping precincts for customers looking for original brand-name goods. Traders' interactions with customers tend to be more anonymous than seller-buyer relationships surrounding the exchange of goods that constitute everyday essentials. Their associations supervise some competitive issues such as access, but not others, for instance pricing. The three main markets for electronic appliances in La Paz were established between the 1960s and 1980s by rural Aymara migrants mainly from the department of La Paz, but they have since become more diverse. Whereas wholesalers are typically middle-aged or senior married couples with adult children (among them a significant number of Aymara and Quechua women born in the countryside), at the area of the retail site of Eloy Salmón, the average trader is younger and male. The area is also more heterogeneous than the wholesale market in both social and ethnic terms and in levels of formal education and business prospects.

Likewise, electronics traders have not only maintained long-term business relations with intermediaries at the free trade and industry zones of Iquique in northern Chile and Colón in Panama-as traders across different commodity groups have - but also with the regional and national representatives of the multinational electronics corporations whose goods they sell. This engagement has sharpened traders' awareness of their position in the market.

While the strong standing and bargaining power of traders' unions - among other unions, peasant, indigenous, and neighborhood organizations - is a historical feature of Bolivia that gained momentum under the left-wing government of Evo Morales, the market relationships and power struggles analyzed in this article are not unique to Bolivia, nor do they merely respond to the current state of the economy. Throughout Latin America, indigenous and popular economic actors operating on the margins of the official economy succeed in satisfying the consumer demands of the urban lower and middle classes (Antrosio and Colloredo-Mansfeld 2015; Thomas 2016; Dewey 2020). As recent studies in economic anthropology and sociology have shown, to look closely at socioeconomic and cultural processes (informal but persistent social relationships, the combination of mutuality and secrecy, local business ethics and pragmatic understandings of branded commodities and "copies") in everyday market life facilitates a nuanced understanding of social 
forms of economic regulation. These differ from universal market models (Gudeman 2008) and may even be illegal, but they produce positive socioeconomic outcomes, jobs, and income, as well as expectations of upward mobility and well-being. From Guatemala (Thomas 2013, 2016) to Argentina (Dewey 2020), Ecuador (Antrosio and Colloredo-Mansfeld 2015), Peru (Ødegaard 2008; Gandolfo 2013), and Bolivia, self-account traders and small-scale producers exhibit productivity in the face of state and corporate projects that aim to marginalize their practices.

\section{THE EAST ASIAN MULTINATIONALS IN BOLIVIA}

In 2016, young Bolivian employees of the Asian multinationals I interacted with still marveled about an incident that had happened a couple of years before: LG had tried to work preferentially with a sole distributer in Bolivia - a department store from Santa Cruz, the wealthier, more Westernized regional capital city in the lowlands. In response, electronics traders from the main marketplaces across Bolivia collectively started a boycott of the brand. They demonstrated in front of LG's headquarters in Santa Cruz until the company finally backed down. Similar oppositional reactions reportedly took place when Samsung aimed to install its own delivery service in La Paz, and a few years before, when it also had tried to circumvent regional commercial mediation.

During the time of my fieldwork, the multinationals' middle managers considered similar initiatives - trying to force market distribution abruptly in a new direction by misrecognizing traders - inefficient. LG Electronics had to learn that such initiatives could produce a loss of sales (because of the boycott). Likewise, the product manager of the smartphone sector at Samsung's national headquarters in La Paz considered legal actions against traders' occasional infringement of intellectual property rights (IPR) rather a "loss of resources," because in Bolivia "it is so complicated to solve this in a reasonable time span."

Yet, instead of leaving the country, as Sony and other music labels had done in the economically volatile and politically instable late 1990 s and early 2000 s, ${ }^{10}$ the electronics multinationals stayed and changed strategies. My interviewees framed the Bolivian market as "unique" and extremely complicated, but also as highly attractive. During a stark expansion of the market for electronics between 2005 and 2019, sustained by continuous economic growth under the MAS (Movimiento al Socialismo; Movement for Socialism) government of Evo Morales and redistribution policies that increased consumption levels among the middle and lower-middle classes, ${ }^{11}$ the East Asian electronics multinationals kept and even amplified their presence in Bolivia. While they had come closer to the Bolivian 
market over the previous two decades, opening regional branches in Santiago de Chile, logistics outlets at the free trade zone in Iquique, and national headquarters in either downtown La Paz or Santa Cruz, they finally became physically present among traders. Sony Electronics was the first to open a showroom and back office in the popular commercial Max Paredes district in 2003. LG and Samsung Electronics followed Sony into this area in 2007 and 2012, respectively, and Huawei joined in 2016.

These four East Asian multinationals have followed a dual strategy in the country: direct sales to a handful of institutional clients (the three telecommunication companies who operate in Bolivia and a few official retailers in shopping malls, mainly in Santa Cruz) and more mediated relationships with traders and shopkeepers in what is called, using the English term, the open market. This marks a significant administrative, social, and symbolic divide. Whereas relations with the small number of institutional and high-end clients (negligible in terms of market share) are managed by the mid-level corporate staff in the national headquarters, following regional corporate hierarchies, the engagement with traders is put into the hands of low-paid personnel, hired under worse terms than the headquarters staff. ${ }^{12}$

Among Samsung's corporate staff, the terminology of the open market has replaced the notion of the informal market that is still occasionally used, though only in more casual conversations. The open market is the official term that simultaneously hints at a locus and indexes an unwelcome relatedness and connectivity of actors and goods. The lower-level employees deploy the term to speak about where they work: the popular retail and wholesale areas. In this sense, they are emplaced in the open market, in contrast to the administrative staff and mid- and upper-level managers "down there in Calacoto," a business district in the upper-middle-class southern zone of the city. This spatial distinction follows the socio-racialized urban geography of La Paz. Since its creation at the beginning of the twentieth century, the Zona Sur has been known as the "white" middle- and upper-class neighborhood of the political and professional elite. In contrast to the headquarters, set off in the southern district in a fancy glass-and-steel building, the open market is open air, messy, and physically demanding.

From the point of view of the middle managers in Calacoto, however, the open market primarily refers to complex and illegible market channels and transactions. It consists of a bundle of commercial routes, networks, and market exchanges that exist outside of corporate oversight. Goods destined for Bolivia are shipped to the port of Iquique and brought to the nearby free trade zone, where 
a handful of official distributers - a mid-sized firm from Chile, merchant migrant businesses from India and Lebanon, and, in the phone sector, also a U.S. firm-receive them. Once these distributors sell them to Bolivian traders, the multinationals lose track of "their" merchandise. ${ }^{13}$ The goods get diverted from the envisioned supply chain into opaque market channels. The Samsung managers contrast these complex distribution channels with what they consider a universal tendency for progressive "formalization": the development of mass retail with the corresponding geography of distribution centers and chains controlled from the top down. This is what they had learned at university and by working for global enterprises. Critically addressed, they aimed at deploying strategies and devices to realize a "universal model for the market" (Gudeman 1992), though not for a market as a neoclassical abstraction, but for very concrete corporate-controlled channels, prices, and sales.

The laborious work of open-market corporate employees in $\mathrm{La} \mathrm{Paz}$ is to re-register the products - to a certain degree, as traders hesitate to let them enter their warehouses. Another instrument is on-the-ground market research. Samsung's head of marketing at Calacoto, for instance, has to send weekly reports to the regional headquarters in Santiago de Chile with information about the sales and prices of Samsung products, as well as numbers on the competition. The most important strategy has been to deploy trade marketing and merchandising. For all of this, the middle management relies on the ceaseless work of lower-level corporate staff. Samsung had twenty-nine employees in the open market of La Paz in 2016 and 2017, a remarkably big team showing the significant labor costs necessary.

\section{Loyalty Marketing in the Open Market}

Noticeable social and professional differences exist between the headquarters and the open-market staff of Samsung Electronics in La Paz. The three middle managers I interviewed hold master's in business administration (MBA) degrees from the Bolivian Catholic University, the elite private university in Bolivia. They are in their forties and fifties and had prior experience with other multinational corporations in Bolivia. In contrast, most of the open-market staff were in their twenties and had gone to public universities or private ones with little cachet, and not all had finished their degrees. Only three of them wanted a career within the corporation. They already stood at the top end of the open-market hierarchy as promotores and supervisores, ${ }^{14}$ had more frequent contact with the Calacoto managers, and were longing to move on to more analytical tasks and greater strategic re- 


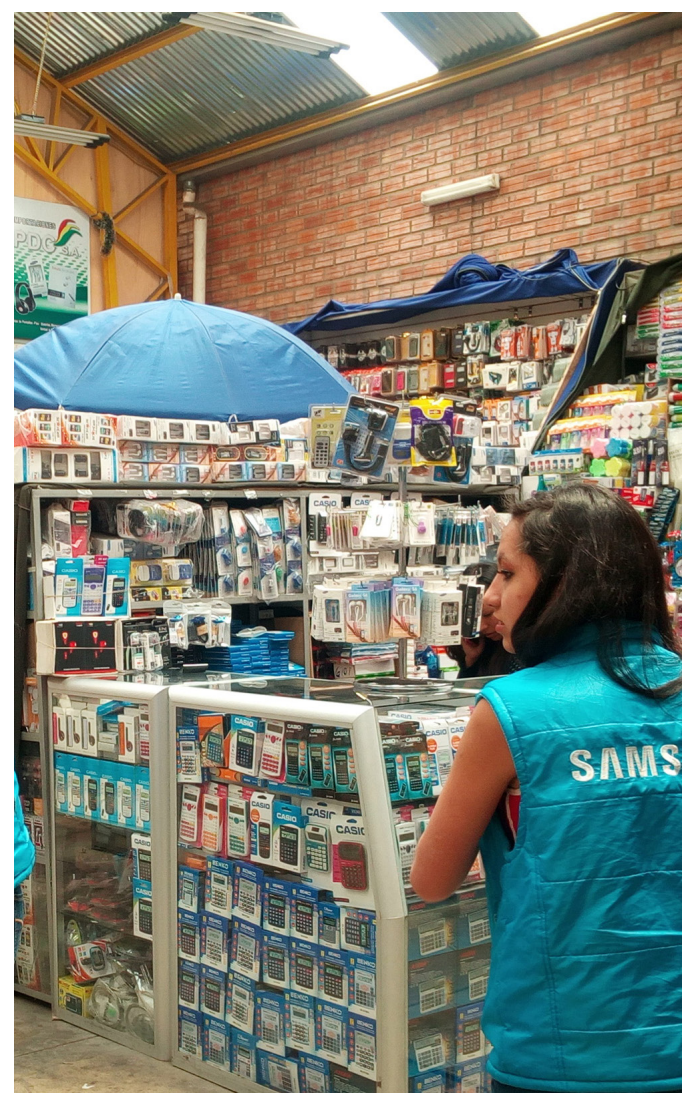

Figure 1. Samsung sales assistant at work in a covered market for mobile phones, gadgets, and small electronic products in La Paz. Photo by Juliane Müller.

sponsibilities in the headquarters. Boris,${ }^{15}$ who had studied economics and worked for the municipal government for six months before joining Samsung, stressed that he had to learn how to "talk" to the traders in an area with which he was not familiar. He respected what he considered "their customs and traditions." Similarly, the head of marketing at LG presented her socialization with the traders in a language of corporate responsibility and affective paternalism. Not only did she have to "be with them every day" but she also had to "take care" of their needs and concerns. Davida, a Samsung consumer electronics merchandiser who had trained as a lawyer with an additional qualification in marketing and who lived in Irpavi in the Southern Zone close to Calacoto, said she had to make efforts to overcome her own prejudices. The work differed from what she had imagined. She wanted to work for a "prestigious international brand," with all that that meant, but had 


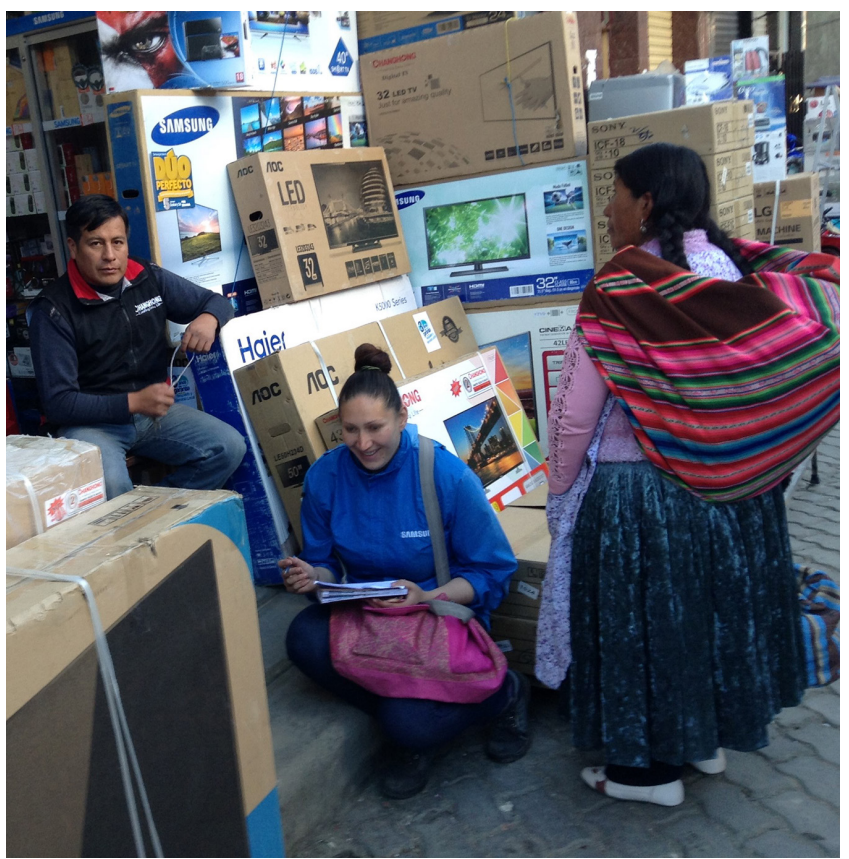

Figure 2. Labor-intensive market research in the open market: Merchandiser with questionnaire while the vendor attends to a customer, La Paz. Photo by Juliane Müller.

ended up in the messy open market. Some colleagues had not been able to cope with this and had left.

Yet other merchandisers and the sales assistants I hung out with during my research stay at Samsung's office felt much more at home in the open market. Emilio appreciated the "freedom" and "conviviality" of the market, as well as his close interactions with the traders, through which he came to know their life stories. Emilio had grown up in the district of Max Paredes, where his parents continued to live. Although he had studied international commerce, he visibly felt closer to the Spanish-speaking world of popular trade with strong Aymara cultural influences than the world of business administration and its adoption of English terms and concepts. He strived to be an electronics trader himself. Likewise, Alisa toyed with the idea of using her savings as seed money for a small independent business in Eloy Salmón. Although she had not previously been as familiar with the world of popular trade as Emilio, she found it attractive and especially compatible with caring for her son. In our conversations, she complained about her current low salary and compared it to what she could potentially earn as a trader with a small shop, or even as the employee of a shopkeeper. As an employee she could make additional money through her own efforts - as vendors usually receive 
a commission for each sale from the shopkeeper — while as a subcontracted sales assistant for Samsung she received no additional reward beyond her salary. ${ }^{16}$

Alisa captured both the unacknowledged importance of her role and the embodied and material quality of her daily work experience when she said to me: "We are the eyes of Samsung; we are gold for them. Their reports are based on the data we provide." Emilio equally highlighted his situated knowledge and informed familiarity: "Down there, they don't know anything; we tell them about prices. It is in the market where the knowledge is produced." These are strong statements about the epistemic value of "local knowledge" (Gudeman 1992) on which the deductive analyses of aggregated data at the headquarters ultimately depend. For Emilio, the management was too far away; it did not know the traders and had no idea about the market. In fact, the physical and social distance, as well as the knowledge gap, was why the multinational corporations created the open market positions in the first place.

\section{Traders' Lack of Fidelity}

Even with a branch office at the heart of popular commerce, the supervisors of these offices and the higher ranks of multinationals had to recognize that it was not only essential to be physically close to the traders but that they needed employees to "fidelize" (fidelizar) with traders, who were considered notoriously "disloyal" (desleal) by the corporations' middle management. The head of the LG showroom commented in our interview in September 2013:

Now we are next door to everything. We hear about everything. Our promoters see the market every day. People are very special; we have to visit them every day. ... The treatment is complicated, highly complicated. You have to create fidelity.

What does it mean to "be next door to everything"? Or, put another way, to not "leave traders unattended," a statement I heard in my first interview with a Sony open-market employee, also in 2013. He told me about the recent months during which they had left traders and vendors "unattended" because of a global restructuring of the company. As a result, their brand had lost visibility, all their advertising banners had been replaced by those of the Korean competition, and sales had fallen considerably.

On a Friday morning during my research stay with Samsung, I accompany Boris on his tour of one of the indoor marketplaces that are regional hubs for 
mobile phones and tablets, brand-name and otherwise. On our way to Doña Sofía, Boris tells me that she is a Samsung "A client," selling five hundred to eight hundred phones a week. For her "loyalty," Boris adds, the corporation invites her on business trips, recently to the International Business Fair in Santa Cruz. After a little bit of small talk and easy laughter at her stall, Doña Sofía takes us toward the entrance of another market building where she owns another sales outlet. She needs more glass display cases. Customers like Doña Sofía get all the furnishings they request. Part of the deal is that traders use them as the corporation intends and collaborate in "looking after the image." This, however, does not necessarily turn out to be the case. Touring the market with Grover, another promotor, we see a Samsung-sponsored shelf used to display Huawei cell phones, and a TCL commercial played on a Samsung flat-screen television. Grover immediately approaches the shops and politely asks the vendors whether they have received the Samsung commercial. He will make sure they get it soon. These are examples of what it means to be close to everything.

As a business concept and subcategory of marketing, merchandising first appeared in U.S. manuals at the beginning of the twentieth century, from which point on it spread around the world as a shorthand for formalizing the presentation of consumer goods (Freidberg 2007). The creation of point-of-sale aesthetics makes for a key instrument. At the open market in La Paz, the merchandisers work toward creating a high-end point-of-sale aesthetic within a sea of improvised-looking infrastructure and built environments; they aim at creating branded shopping environments inside traders' tiny shops and at stalls of no more than two square meters. Traders hardly oppose these changes in the presentation and placement of the brand-name goods, which include putting them in what Boris termed the "golden zone" — international marketing jargon for those areas in plain view. For the traders, this adds to the visual attractiveness of the shops and the market as a whole, something widely appreciated. Emilio told me that he enjoyed working in merchandising because he "especially liked the image." He believed that the products must "enter" customers' awareness entirely "through the eye." Emilio's words resonate with a widespread idea among traders about attracting customers through the display of varied, colorful, and indeed opulent amounts of products. It is this visual impression of plenty and "abundance" (Tassi 2010) that is further enhanced by professional merchandising and welcomed by traders.

The traders feel less at ease, however, with those corporate initiatives that go beyond the mere presentation of the goods to address storage, prices, and sales. Traders have a strong idea of their standing as cuentapropistas vis-à-vis the enter- 
prises and an acute awareness of their genuine interest in not fully complying with merchandising agreements. For Gonzalo and Eduardo, two young games-console and smartphone vendors who share a nicely decorated shop with branded shelves up front, their business clearly depends on diversification. At the beginning of 2020, they sold about 50 percent Samsung phones, only 20 percent Huawei but about 30 percent Xiaomi, and not all of them new products. Some were older models or refurbished items. When I asked how this worked out with Samsung and Huawei, the two men admitted that they were doing some sales "more under the table" (más por debajo) and even "underground" (clandestinamente). To my knowledge, no explicit agreements or contractual obligations exist about brand exclusivity, which is something traders openly oppose. There is in place, however, a certain understanding between individual traders and the corporations regarding common objectives that call for the preferential sale of new and brand-name items. Subverting this understanding proves effective and gainful for traders, but it undermines efforts to create the type of demand for "authentic" brands most profitable for the corporations.

\section{The Casero/a Idiom}

In line with this diversion from target agreements, it is important for multinationals to make sure that traders not only adequately display their goods, but really recommend them - and not those of the competition. This is the main problem of brand "infidelity." As a Sony staff member commented, "They are capos [crafty, clever] here. A customer comes in to buy a Sony but leaves with any other brand." Without vendors' engagement and proactive recommendations, even the most nicely displayed good can remain a shelf warmer. Part of multinationals' obligatory learning process was their recognition that traders are powerful commercial intermediaries, without whom merchandising can be wasteful, as it might fail to produce the desired rise in sales.

Vendors' power of persuasion has various dimensions. There are long-lasting mutual commitments known as casero/a (regular client or provider) bonds. These have been described for trade and markets across the Andes (Buechler and Buechler 1992; Seligmann 2004; Tassi 2016). In the electronics trade, these client-customer bonds are salient between wholesalers and retailers at different points of distribution. At the electronics marketplaces in La Paz, however, interdependencies are weaker, as many street traders and shopkeepers sell to customers from across the metropolitan area. Yet the interpersonal connection between buyer and seller continues to be a powerful mutual expectation. Retailers' calling out to un- 
known passers-by with caserito, or with phrases such as "caserita, just ask" (caserita pregunta no más), promise good offers and a willingness to answer any query the client might have. Customers also call unknown traders caseros, which places a moral obligation on them to sell good merchandise for a low price. The casero idiom and related gestures imbue the market encounter with a sense of responsiveness that facilitates mutually satisfactory transactions. It must be understood as part of a wider range of etiquette and performative signs that indicate respect across social, gendered, and ethnic-racialized boundaries, which have historically been stark in Andean societies. ${ }^{17}$

The prevalence of the casero/a language in the market and the expectation of mutuality constitute major challenges for the corporate open-market staff. It seems as if their presence in the market and the interactions with traders are never intense or strong enough. The personalized attention they give can easily be considered too little, especially by elderly wholesaler women, such that they get annoyed and stop responding. The day I toured the market with the head of the Samsung showroom in 2017, the first thing we had to do was reach out to a client he considered "B," an importer-wholesaler of television and entertainment equipment. She had to be put at ease after not having been invited to the latest business dinner. Favors or favorites appear impossible to keep secret in the open market. Traders tend to expect a reciprocal exchange of information and contacts, in addition to gifts and bonus payments, without which a relationship of loyalty is hard to create and maintain. Emilio picked this up by emphasizing that he-in return for the numbers about sales and prices traders shared with him for his obligatory weekly market research tour-gave advice about international commerce, business administration, and similar topics. The corporate classification into A, B, and $\mathrm{C}$ clients according to purchasing power was visibly at odds with what traders expected from business partners: that loyalty and longevity were as important as quantities of sales.

Likewise, the channel specialists' task to get hold of products as soon as possible on arrival in La Paz proves challenging as traders jealously hide access to their deposits. Once scanned by channel specialists, products — which had been circulating and sold among Bolivian importers, wholesalers, and retailers out of manufacturers' sight — become part of a digitally trackable chain. Yet traders only allow a few select employees to enter and see what they have in stock. Again, as for merchandising, to build inventory, corporate staff needs to be in daily contact with traders, renewing and confirming reciprocal bonds. Significant energy on the part of employees goes into the simple task of finding out about arrival times and 
contents of truckloads. To my knowledge, the multinationals are significantly less successful with inventory building than with merchandising.

In sum, the open market embodies the antithesis of an efficiently managed chain of adequately placed, framed, and commercialized brand-name products. Although the manufacturers, especially Samsung Electronics, employ significant human labor and technological devices to render traders' market channels legible and their own products predictable, they have done so with limited success. Traders like the visual effect of merchandising but hesitate to disclose numbers, prices, and stock. The corporations have not managed to overcome racialized class differences inscribed in the urban landscape and have failed to fully adapt to vernacular commercial language and traders' expectations of a mutual exchange of favors and information. The international business jargon stands at odds with local, Aymara-influenced Spanish market etiquette and creates a social and symbolic boundary between multinationals and traders. The challenges to creating brand fidelity with traders are replicated with the open-market employees, who are aware of their low status within the corporate national and international hierarchy. Under these circumstances, independent trading seems a more attractive and feasible medium- and long-term option than remaining within the corporate world. Furthermore, because of the tangible experiences and contacts, Emilio, Alisa, and other open-market staff find themselves in a privileged position to start their own businesses. I will now switch perspective and analyze the workings of market channels, handling, and pricing from the point of view of wholesale and retail traders to further interrogate vernacular market efficacy.

\section{MARKET CHANNELS AND THE PRAGMATICS OF PRICING}

At any of the three markets for electronics in the Max Paredes district, one will find neither a wholesaler who has the best offer across product categories and brands nor a retail shop or stall that offers persistently low prices. Although wholesalers have usually specialized in one or two brands, sometimes complemented by their own store label, as well as in one commodity subgroup, they rarely sell all types of LG white goods, for example, or all sizes of the Samsung flat-screen television, or the complete set of Huawei phones. Likewise, the distinction between wholesaler and retailer is frequently made in the market to refer to the trader's main activity, but layers overlap. The same trader might be an importer-wholesaler for certain products, a person that "brings over" (trae) this merchandise, but a secondary wholesaler or a simple retailer for other items. Traders are situated at different linkages (eslabones) in fragmented transnational market channels. Their 
offers - although many strive for an oferta surtida, a varied, well-stocked offer of the products in the commodity subgroup they handle - are far from complete and follow a different logic than brand-centeredness or price coherence. As a result, there are different prices available for the same product, depending on the specific channel, the moment of the transaction, and social variables, such as the nature of the seller-buyer relationship.

In this regard, Don Francisco, an importer-wholesaler of toners and printers who owns a shop with his wife, told me with conviction, "we"-meaning cuentapropista traders in general_ — never keep track of prices. He showed me his Excel table with the serial number of every sold item (for possible returns), the name of the client, and the day of the transaction. It mentioned nothing about prices. Wholesalers handle prices with an air of secrecy and know where their loyalty is primarily directed: toward their providers and clients, not toward the multinationals. When I visited Don Francisco on a rainy day in November 2015, he was attending to a wholesale customer from as far as Sucre in the region of Chuquisaca, a ten hours' ride from La Paz. As an in situ demonstration of what he had just told me, namely, that he had geographically dispersed clients and providers, he received a phone call from Miami. After animated small talk and laughter, he negotiated a direct order of Canon printers and ink cartridges with the Spanish-speaking dealer on the line, commenting at once playfully and triumphantly, "we are gaining over Canon.”

\section{Retail Price-Setting and Modes of Valuation}

Unlike other classic loci in economic anthropology, such as agricultural marketplaces (Geertz 1978; Alexander 1992; Gordon 2010), where there is little product innovation, or the low-end street sales of homogeneously cheap merchandise, price-setting for electronics in the open market in La Paz is complicated by the growing number of brands and the proliferation of internal value classes for each brand-name model. The big electronics manufacturers, driven by the need for novel products year after year to maintain high profit levels, contribute to this overflow of goods, especially in ICT (information and communication technology). For each fancy new ICT product launched globally, the offer in the Bolivian market is usually tripled. The Galaxy S8, for instance, exists in different versions due to internal categories or "scales of value" (see Guyer 2004, 83-96). These are an original with an official warranty for Bolivia, an original without this warranty, and a fake in one or the other way, called either after the site of production (chinito, meaning from China) or hinting at its dubious quality (trucho). These cate- 
gories can be further subdivided as each of these products exists either as a new good, a second-hand item, or a refurbished product.

Anthropological studies on counterfeit products and sales, mostly concerned with imitations of international fashion brands in places as Nigeria, Vietnam, and Guatemala (Guyer 2004; Vann 2006; Thomas 2013), have shown that customers do not necessarily distinguish products along the simple binary matrix of the fake versus the original, or the copy versus the real brand. This binary is codified in international IPR and related to Western notions of ownership and authenticity (Thomas 2013; Dewey 2020), but it does not hold everywhere. In La Paz, the prestige of a name like Samsung also rubs off on its imitators. Before the multinationals' engagement with popular marketplaces, traders and shops already visibly announced the commodities they were selling by using a copy of the logo with the right typeface and color. This violates IPR, as logos form part of the protected “object-signs" (Nakassis 2013, 111); but it attracts customers who look, if not for an original (original), then for a copy that promises to be better than imitations of less well-known brands. ${ }^{18}$ Customers I spoke to commented that they looked for a reliable product, whether original or not, that would not break down.

In La Paz as elsewhere (Vann 2006), customers tend to make pragmatic judgments about whether a product is worthwhile or not. The average customer does not perceive a copy as necessarily bad or fraudulent. A defective product or a totally different item would be considered a fraud (see Guyer 2004, 92-93), for example, if you bought a new water heater and found the box filled with a broken one, or with plastic cups. This is something rarely seen in Bolivia, as boxes are always opened before a purchase, so that clients can a have a close look at the product and touch it. Once a customer is inclined to buy, the merchandise's functioning is tested. Even stall vendors have an electrical outlet available to do so. This marks one of the differences between wholesalers and retailers: the latter test the equipment before the clients' eyes. Shopkeepers and more established stall vendors also offer their own warranty, in cooperation with nearby technical workshops, usually for several months.

Retailers' gainful margins rely on a combination of social and situational factors (as in other trades), as well as on elements specific to the value scales of electronic products. From time to time, these gains rely on small deceptive acts, such as overpricing a good and playing with product scales. An Oster mixer might be sold as original with an official warranty for Bolivia although it does not have one. ${ }^{19}$ I regularly visited a stall vendor of small household items who sometimes highlighted the watt potential of the Oster mixer for 160 Bolivian boliviano (about 


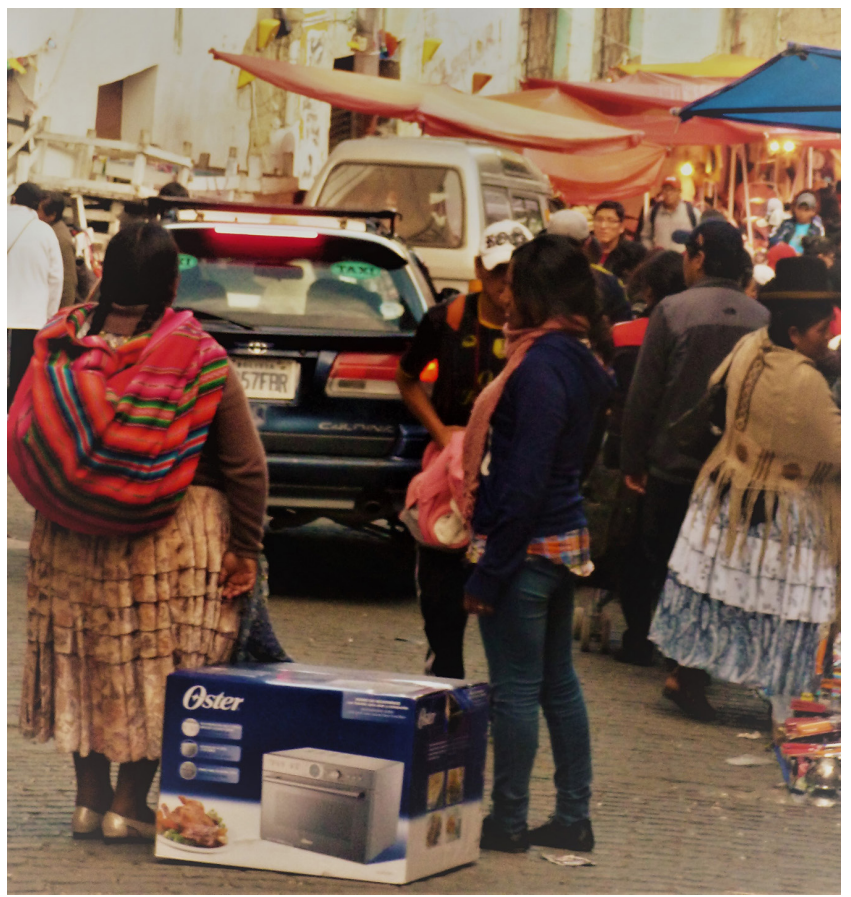

Figure 3. Clients, probably mother and daughter, after purchasing one of the popular Oster household appliances, La Paz. Photo by Juliane Müller.

USD 26.50), whereas on other occasions he would stress the reliability of the 180-boliviano Philips mixer. With yet another type of client, he would stress that this or that product held an official warranty. What differentiates the products according to international legal regimes and corporate interests (the official warranty) appears here as just one among many criteria that define the characteristics of products. Although traders are accustomed to highlighting the product's technical and practical advantages according to their on-the-spot assessment of a client's preferences, and a consideration of their own need to sell this or that product, self-interested tactics are limited by the mutual expectation that both retailer and customer will build a good relationship and start to form a casero bond.

From the multinationals' perspective, this looks quite different. Imitations are, contrary to expectation, not much of a worry for the manufacturers of ITC and entertainment equipment, the fastest growing sectors in urban markets. "They do not do much harm," the Samsung open-market supervisor commented in this respect. By contrast, the originales without a manufacturer's warranty for Bolivia created a bigger issue. From the multinationals' perspective, these constitute "parallel imports" that ought not to be in Bolivia. ${ }^{20}$ They are not illegal except under 
private commercial law, ${ }^{21}$ but they make for a costly annoyance for the corporations. Because the parallel imports are hard to track, they make it difficult to generate data about sales, anticipate future demand, and assure corporate accountability for the products sold.

Since 2016, one measure to combat parallel imports in Bolivia has been to create a novel value class. These products are called homologados (authorized; validated) or plus. They have been created mainly by Samsung and Huawei in a process of mutual copying and borrowing of strategies. From the traders' point of view, the homologado is a product with an official warranty for Bolivia - it is that simple. For the corporations, it should be a fancy and superior kind of branded good, not just original but, as the Samsung staff stresses, "authenticated for Bolivia." Customers are induced to perceive qualitative differences and spend more money for this added value. Apart from being positioned in branded spaces as described, some homologado phones have extraordinary packages - another key strategy of merchandising. By advertising them as specifically "made for Bolivia," Samsung tries to connect with ideas about unique Bolivian culture and respond to economic nationalist sentiments promoted by the MAS government.

This strategy of requalifying originales as homologados is made by means of a distinction between two basically identical products; although this might seem paradoxical, it is a rather common marketing strategy (Callon, Méadel, and Rabeharisoa 2002, 202-4). Homologados are not technically better in any way than simple originals (both types are usually materially unaltered brand-name products), but they cost about 5 percent more. The difference generated between an original and a homologado potentially increases the number of customers who can choose between classes of the same Samsung and Huawei product model. In this sense, the homologado might be interpreted as a premium "brand extension" (Foster 2007, 708), with the peculiarity that the homologado appears to be "more legal" than the original. A bundle of features serve to entice the customer: the notion of purchasing the official and authenticated "world-class" brand; a manufacturer's warranty for Bolivia; and special sales and entertainment offers through the manufacturer's smartphone app. To activate their welcome package, clients are invited to visit Samsung's showroom and register. There they receive personal attention from the Samsung open-market staff and can validate their newly acquired product. In this way, they experience being part of the "real" company.

Still, as market transactions remain in the hands of traders, the effectiveness of the new value classes rises and falls with traders' recommendations and sales. For instance, wholesale traders' commitment to building long-term relationships 
up- and downstream means that they do not always go for the homologado product, although both wholesale and retail traders as well as vendors receive a special high bonus payment for the premium products, constituted by the newest and most expensive homologado products. Price dispersion and gainful margins on the threshold of value classes mean that homologados, even with the bonus payment, are not always the most lucrative option for retailers. Moreover, they feel obliged to serve the needs of heterogeneous clients and "all kinds of pockets" (todos los bolsillos). This most likely serves traders' own medium- to long-term advantage: if a certain brand loses popularity or an economic downturn heightens peoples' price sensitivity, they must be able to offer alternatives. Diversification, identified as the most important strategy of popular economic actors in the Andes (cf. Zoomers and Mitzman 1999; Seligmann 2004; Tassi 2016), continues to prevail among electronics traders and is seen as vital to success. This is not principally a pluri-activity, as in rural and peri-urban settings and less lucrative trades, but refers to brand diversification and the use of proliferating value scales to achieve a gainful margin. By working at the interstices of value classes, and setting and keeping secret their fluctuating prices, traders not only demonstrate how prices reflect power struggles (Çalişkan and Callon 2010; see also Alexander 1992) but also defy the legitimacy of protecting corporate profits through private commercial law. They contest homogenized pricing and the illusion that only one "authentic" brand-name product exists, with its corresponding price.

\section{CONCLUSION}

The electronics multinationals struggle to monitor the movement of their products in South America and to fix their locations, prices, and identities in La Paz. The brand-name products destined for Bolivia become detached from the digitally trackable distribution chain by entering popular market channels. Transactions between Bolivian wholesalers and official and nonofficial providers in the free trade zone of Iquique, in Miami, and other places in the region embody this point of detachment. In La Paz, the multinationals try to regain an overview of their products and convince traders to cooperate with inventory control and help with loyalty marketing. Yet traders themselves lack brand fidelity. Despite the offer of monetary incentives to comply with corporate marketing, traders' primary interests and loyalties continue to lie elsewhere. Merchandising is welcomed, as it heightens the attractiveness of shops, stalls, and the entire market by upgrading these aesthetically and transmitting reliability and prestige. Yet the brand image not only indexes the homologado; it also shapes the reputation of the shop and stall 
owners as traders of branded goods who, nonetheless, need not restrict sales to these products. Traders reject product standardization. To have a few premium products in plain view does not hinder traders from selling older models, second-hand phones, and parallel imports, or from caring for casero customers. The "social price" (Roitman 2004; Seligmann 2004) retailers arrive at with clients depends on interactional dynamics within the wider framework of expectation that the relationship lasts beyond a single sale.

The institution of caseridad is fundamental to understanding the efficacy of vernacular markets. To care for a personal network of providers and clients promises to be meaningful and lucrative for traders at different points of distribution. When asked about economic prospects, traders most often refer to their contacts and partners as a guarantee for present and future successes. Likewise, customers can reasonably expect to find a better price with a retail trader with whom they already share a transactional history and expect to buy from in the future. The sociality that is a fundamental part of commodity exchange through the workings of caseridad has further implications. It has created an idiom of relatedness and mutuality in the market, and casero bonds also channel important commercial knowledge and price information. As prices vary according to the moment, value class, and the social relationships among transactors, competition also depends on many elements and is not centered on prices only. This allows for the coexistence of hundreds of traders with different business prospects and facilitates market entry. Becoming a vendor of an established shop, as a door into retail trade or to opening a small business of one's own, tends to be more attractive than working as a corporate employee in the open market. For some of the employees just described, this had to do with the human quality of market relations. In this regard, the viability and desirability of a vernacular market depends on the production of entangled economic and social value.

What does this tell us about commodities at the current global conjunction of corporate chain management and branding with vernacular market transactions and channels? The contemporary brand seems to be the fully accomplished commodity form as to Marx's understanding: it is not only material and immaterial, equipped with use and exchange value, but embodies an "excess of social meaning and value - a brand fetish . . . that always reaches beyond itself, beyond (but through) exchangeability into another realm of value" (Nakassis 2013, 113). This other realm is social life with its moral values and emotional attachments. From the mid-nineteenth century onward, corporate brand marketing has tried to forge an imaginary that invokes "fidelity, standardization, quality control, and trust- 
worthy distribution" (Nakassis 2013, 114), capable of creating emotional experiences among consumers (Foster 2007; Gershon 2016; see also Applbaum 2004). As elsewhere, at Bolivian marketplaces corporations try to achieve this by relating concrete and bounded commodities with other visual and material elements such as trademarks, labels, packages, shelves, and advertising banners and films to create an unbounded brand image and the "affective dimension of the person-product relationship" (Foster 2007, 708). Yet from the perspective of distribution, some of these assumptions must be problematized as well as the equation of brands and commodities. It offers an ethnographic inquiry into the potential failures of corporate branding that proves important not least to counterbalance predominant success stories (Manning 2010, 34). The circulatory sphere between production and consumption is not only crucial for corporations in their attempts to forge the brand image and control the commercialization of knockoffs and counterfeits (Dent 2012) — and otherwise unwelcome products such as parallel imports; from the perspective of traders and other commercial intermediaries, it also makes for a crucial domain in which commodities are potentially "de-branded."

In La Paz, corporate branding hardly debases the logics and meanings of commodity exchange among traders. The commercialization of electronics is based on interpersonal loyalty, idioms of mutuality, and pragmatic valuation that promise to deliver not quality control and standardization, but satisfactory combinations of price, quality, and degree of authenticity. To this day, the multinationals have not managed to destabilize the transactional routines and attachments that characterize the markets' efficacy. It is the social, affective, and material texture of the vernacular market, and peoples' understandings of what makes it worthwhile and successful, that offers a substantive understanding for why the electronics get diverted from distribution chains and escape the fixation of brand marketing. The manufacturers face challenges to reclassify the products according to their interests because they cannot detach them from established connections and infrastructures. In this regard, the circulation of commodities beyond the outlined paths entangles them in variable relationships with peoples, spaces, information, prices, and value scales that differ from the fixed relational elements (such as trademarks, commercials, and packaging) making up the brand. The commodity is caught up in interpersonal attachments that complicate the creation of the kind of surplus value characteristic of the brand form (see Foster 2007). In the contemporary economy, with its networks and logistics that span the globe, we observe important power struggles over market distribution and valuation — not only between economic actors (such as traders and corporations) but also between different pro- 
ductive processes and, indeed, collective forms of value creation. Such a regime of value of vernacular markets is not a preexistent and bounded system, nor a rigidly separated space from corporate capitalism (Çalişkan and Callon 2009, 387); rather, it emerges from prolonged socioeconomic practice and bottom-up market making amid global connections.

\begin{abstract}
This article offers a nuanced ethnographic description of the encounter between multinational corporations and the economic actors who distribute and commercialize their commodities. By analyzing the labor of lower-level employees and the strategies of the middle management of Samsung Electronics Bolivia against traders' practices and understandings and the vernacular market infrastructure, I offer a substantive interpretation of the obstacles and unintended outcomes of corporate commodity chain and brand management as it expands into an "emerging" market such as that in Bolivia. Street vendors, shopkeepers, and wholesalers are teased with personalized attention, gifts, and monetary incentives to sell the high-priced premium brands and build legible inventory, but they have remained notoriously disloyal. By focusing on the agreements and tensions between corporations and traders about how to move, store, categorize, advertise, and price the products, this article engages with the literature on urban marketplace trade and commercial transactions, counterfeit commodities, and economic power in globalized markets and supply chains. To think about the appeal and effectiveness of vernacular market channels and arrangements offers a conceptual lens to critically address the efficiency paradigm in supply-chain thinking, as well as to analyze discrepancies and power struggles not only among economic actors (such as traders and corporations) but also between different forms of valuation that co-exist and compete in markets. [multinational corporations; traders; supply chains; brands; valuation; electronics; Bolivia]
\end{abstract}

\title{
RESUMEN
}

Este artículo ofrece una detallada descripción etnográfica del encuentro entre empresas multinacionales y los actores económicos que distribuyen y comercializan sus mercancías. Al analizar la labor y las estrategias de los empleados de Samsung Electronics Bolivia frente a las prácticas y visiones de los comerciantes, así como la infraestructura social, material y afectiva del mercado vernáculo, ofrezco una interpretación sustantiva de los obstáculos en la gestión corporativa de la cadena de productos (supply chain management) y en el marketing (branding) a medida que se expanden hacia mercados "emergentes" como el boliviano. Al centrarme en los acuerdos y las tensiones entre las empresas y los comerciantes sobre cómo mover, almacenar, categorizar, valorar y comercializar los productos, este artículo reconsidera la literatura sobre el comercio de las plazas de mercado, las mercancías falsificadas y los procesos de economización. Pensar en el atractivo y la eficacia de los canales y 
arreglos del mercado vernáculo ofrece una lente conceptual para abordar críticamente el paradigma de la eficiencia en el pensamiento sobre las cadenas de suministro, y permite observar discrepancias y luchas de poder no sólo entre unos agentes económicos (como los comerciantes y las empresas), sino también entre diferentes formas de valoración que conviven y compiten en los mercados. [empresas multinacionales; comerciantes; cadenas de suministro; marcas; valoración; electrónica; Bolivia]

\section{NOTES}

Acknowledgments The article has taken shape after a seminar talk in October 2019 at the Department of Anthropology at the University of Barcelona. I thank the colleagues present, especially Gemma Orobitg Canal, as well as Aditi Saraf, Adolfo García Jerez, and the five anonymous reviewers of the manuscript for their sharp and insightful comments that helped enormously to tease out the most important themes and concepts. I am grateful for the extraordinary support of the editorial collective of Cultural Anthropology, in particular Brad Weiss for his close and constructive engagement. Without the benevolent attitude of the corporate employees and traders, this research would not have been possible. While I decided to keep the original names of the corporations and markets, all individual names have been changed to ensure anonymity.

1. Fieldwork at the main wholesale and retail markets for electronic equipment in La Paz was carried out with traders (wholesalers, store retailers, and street vendors) and Samsung's corporate staff (mainly lower-level employees, interviews were also conducted with middle managers). I also interviewed employees of South Korean LG Electronics, Japanese Sony, and Chinese Huawei and Xiaomi. Throughout the text, I primarily refer to Samsung Electronics, as my main data comes from this corporation. It is investing most in Bolivia's popular markets, but the others do similar things, only with fewer employees and a smaller budget.

2. On street trade, see John Cross and Alfonso Morales (2013) and Karen Tranberg Hansen, Walter E. Little, and B. Lynne Milgram (2013). For an overview of anthropological research on marketplaces, networks, and institutions, see Theodore C. Bestor (2001). On Andean commerce, compare Linda J. Seligmann (2004) and Nico Tassi (2016).

3. This is conventionally expressed in economics as the maximizing and the minimizing principles (of the energy balance, human labor, or overall costs): maximizing the yield with least input, and vice versa, minimizing input for a set outcome goal.

4. Whereas commodity chains evoke a long history of international production and trade, supply-chain management indexes "new profit regimes" (Tsing 2009, 149). The business literature has identified supply chains as the main competitive actors in the global economy (Mangan, Lalwani, and Butcher 2008). They are usually categorized into upstream (production related), midstream (transport and storage), and downstream (marketing and sales to end clients) activities. Supply-chain thinking and management can ultimately be tracked to Toyota's production system and lean manufacturing.

5. My use of efficacy differs from that of Janet Roitman (2007) who addresses epistemological questions. Still, the idea of thinking concepts "through practices" (Roitman 2007, 158) has inspired my usage of the term. Such an ethnographic development of concepts of course fundamentally differs from the deductive and atomistic methods, mathematical models, and evolutionary-selective thinking of mainstream economics. It also differs from more sociological approaches, such as institutional economics, which measures economic performance by holding certain principles and variables separate and fixed, and believes that only those institutions that solve a range of efficiency problems (with regard to prices, resource allocations, etc.) endure (Ensminger 1992, 23).

6. Actor-network approaches distinguish mediators from intermediaries by ascribing an agentive network capacity to the former. I follow Christian Bessy and Pierre-Marie Chauvin 
$(2013,96)$ in sticking to the term intermediary, although I highlight traders' active and transformative part in shaping markets.

7. The estimation is based on official data on single-person businesses (empresas unipersonales) in the rubric of home appliances and consumer electronics in La Paz, the number of licensed street traders at the main marketplaces for electronics, and membership numbers from the various associations of electronics traders.

8. We should not equate informality with trading. Whereas an estimated 60 percent of the economically active population in Bolivia work in domestic and semi-industrial units with fewer than five employees (many of them as traders), 65 percent of all citizens do not have a tax identification number (NIT) and almost 80 percent do not contribute and therefore are not entitled to a pension program (Hillenkamp 2013, 49).

9. The number of gremiales in Bolivia is difficult to know. According to their self-description, the number lies between 1.5 and 2 million.

10. Sony Music was present in Bolivia in the 1990s but left the country when music and software piracy skyrocketed (Stobart 2011).

11. According to the UN Development Program, between 2003 and 2013, 2.1 million citizens joined the middle class in Bolivia on the basis of their income (between ten and fifty U.S. dollars of purchasing power), which would be equivalent to a growth of the middle class of almost twenty percentage points (UNDP 2016, 51-52). Even so, on average, 50 percent of the Bolivian population living in poverty (based on their income) did not emerge from that situation during the same period and 15 percent of the former middle class lost purchasing power (UNDP 2016, 66).

12. Samsung engages a Bolivian agency for recruitment. It makes official job offers instead of hiring directly among traders. The boundaries between traders and corporate staff are permeable, but generally in the opposite direction: employees become vendors and retailers.

13. The distributers have business relations with Bolivian traders established over two decades that include generous conditions of supplier's credit (Müller 2018). After purchase, traders arrange transport with semi-informal lorry drivers who are responsible for overland logistics and customs. The multinationals usually know how many products of each model are sold weekly to Bolivian traders (numbers facilitated by the distributers), but not how many arrive at marketplaces in La Paz or are re-exported to Peru. Likewise, brand-name goods that have not passed through the hands of the official distributers and are not officially destined for Bolivia end up in La Paz.

14. To my knowledge, job categories are either translations from English — supervisor (supervisor), promotor (promoter), and asistente de venta (sales assistant) — or have been directly incorporated into the language, as in the case of the so-called merchandisers. In 2017, the promotores were renamed channel specialists, a further example of the usage of international business jargon and Anglicisms in contrast to the world of Spanish-speaking and Aymara-influenced grassroots trade.

15. All names have been changed.

16. The contracts of the open market staff offer salaries above the minimal wage and health insurance at the workplace but used to be flexible.

17. Traders, especially women, embody an intermediate position in Andean societies. Their subjectivity has been historically informed by a position between social and racial categories (Seligmann 1993).

18. Commentaries from corporate staff and traders according to which Samsung should visually dominate the retail marketplaces by "70 percent" offer a telling illustration of brands producing excesses or "surfeits" (Nakassis 2013). Traders interpret this as promoting Samsung in general, not just the authenticated products. Although counterfeits and nonauthorized advertisements might destabilize the brand in terms of quality and accountability, they also strengthen the brand image through omnipresent visibility.

19. Oster household appliances are highly popular in Bolivia and among the products with the highest number of parallel imports and chinitos circulating. Oster and the other most 
successful Western multinationals, such as Philips and Bosch, run the Bolivian market from afar, out of regional headquarters in Miami, Mexico City, or São Paulo, Brazil.

20. Parallel imports are defined as trademark-protected commodities that circulate outside a geographical unit authorized by the intellectual property owner (INTA 2015).

21. In Latin America, as in most regions and countries worldwide, parallel imports are not prohibited by state law unless the products have been modified or damaged - in other words, unless they are "materially different" (INTA 2015, 2).

\section{REFERENCES}

Alexander, Paul

1992 "What's in a Price? Trading Practices in Peasant (and Other) Markets." In Contesting Markets: Analyses of Ideology, Discourse and Practice, edited by Roy Dilley, 79-96. Edinburgh: Edinburgh University Press.

Antrosio, Jason, and Rudi Colloredo-Mansfeld

2015 Fast, Easy, and In Cash: Artisan Hardship and Hope in the Global Economy. Chicago: University of Chicago Press.

Applbaum, Kalman

2004 The Marketing Era: From Professional Practice to Global Provisioning. New York: Routledge.

Bessy, Christian, and Pierre-Marie Chauvin

2013 "The Power of Market Intermediaries: From Information to Valuation Processes." Valuation Studies 1, no. 1: 83-117. https://doi.org/10.3384/vs.2001-5992.131183.

Bestor, Theodore C.

2001 "Markets: Anthropological Aspects." In International Encyclopedia of the Social and Behavioral Sciences, edited by Neil J. Smelser and Paul B. Baltes, 9227-31. Amsterdam: Elsevier.

Bonacich, Edna, and Jake B. Wilson

2008 Getting the Goods: Ports, Labor and the Logistics Revolution. Ithaca, N.Y.: Cornell University Press.

Buechler, Hans C., and Judith-Maria Buechler

1992 Manufacturing against the Odds: Small-Scale Producers in an Andean City. Boulder, Colo.: Westview Press.

Çalişkan, Koray

2010 Market Threads: How Cotton Farmers and Traders Create a Global Commodity. Princeton, N.J.: Princeton University Press.

Çalişkan, Koray, and Michel Callon

2009 "Economization, Part 1: Shifting Attention from the Economy towards Processes of Economization." Economy and Society 38, no. 3: 369-98. https://doi. org/10.1080/03085140903020580.

2010 "Economization, Part 2: A Research Programme for the Study of Markets." Economy and Society 39, no. 1: 1-32. https://doi.org/10.1080/03085140903424519.

Callon, Michel, Cécile Méadel, and Vololona Rabeharisoa

2002 “The Economy of Qualities." Economy and Society 31, no. 2: 194-217. https://doi.

Cowen, Deborah org/10.1080/03085140220123126.

2010 "A Geography of Logistics: Market Authority and the Security of Supply Chains." Annals of the Association of American Geographers 100, no. 3: 600-20. https://doi. org/10.1080/00045601003794908.

Cross, John, and Alfonso Morales, eds.

2013 Street Entrepreneurs: People, Place, and Politics in Local and Global Perspective. London: Routledge.

Dent, Alexander S.

2012 "Piracy, Circulatory Legitimacy, and Neoliberal Subjectivity in Brazil." Cultural Anthropology 27, no. 1: 28-49. https://doi.org/10.1111/j.1548-1360.2012.01125.x. 
Dewey, Matías

2020 Making It at Any Cost: Aspirations and Politics in a Counterfeit Clothing Marketplace. Ensminger, Jean Austin: University of Texas Press.

1992 Making a Market: The Institutional Transformation of an African Society. Cambridge: Foster, Robert J. Cambridge University Press.

2007 “The Work of the New Economy: Consumers, Brands, and Value Creation.” Cultural Freidberg, Susanne Anthropology 22, no. 4: 707-31. https://doi.org/10.1525/can.2007.22.4.707.

2007 “Supermarkets and Imperial Knowledge." Cultural Geographies 14, no. 3: 321-42. https://journals.sagepub.com/doi/10.1177/1474474007078203.

Gandolfo, Daniella

2013 "Formless: A Day at Lima's Office of Formalization." Cultural Anthropology 28, no. 2: 278-98. https://doi.org/10.1111/cuan.12004.

Geertz, Clifford

1978 "The Bazaar Economy: Information and Search in Peasant Marketing." American Economic Review 68, no. 2: 28-32. www.jstor.org/stable/1816656.

Gershon, Ilana

2016 “'I'm not a businessman, I'm a business, man': Typing the Neoliberal Self into a Branded Existence.” HAU: Journal of Ethnographic Theory 6, no. 3: 223-46. https:// doi.org/10.14318/hau6.3.017.

Gordon, Kathleen E.

2010 “'The market sets the price': Determining Prices in a Bolivian Marketplace." Journal of the Royal Anthropological Institute 16, no. 4: 853-73. https://doi. org/10.1111/j.1467-9655.2010.01657.x.

Gregson, Nicky, Mike Crang, and Constantinos N. Antonopolous

2017 "Holding Together Logistical Worlds: Friction, Seams and Circulation in the Emerging 'Global Warehouse." Environment and Planning D: Society and Space 35, no. 3: 381-98. https://doi.org/10.1177\%2F0263775816671721.

Gudeman, Stephen

1992 “Markets, Models and Morality.” In Contesting Markets: Analyses of Ideology, Discourse and Practice, edited by Roy Dilley, 279-94. Edinburgh: Edinburgh University Press.

2008 Economy's Tension: The Dialectics of Community and Market. New York: Berghahn Books.

Guyer, Jane I.

2004 Marginal Gains: Monetary Transactions in Atlantic Africa. Chicago: University of Chicago Press.

Hansen, Karen Tranberg, Walter E. Little, and B. Lynne Milgram, eds.

2013 Street Economies in the Urban Global South. Santa Fe, N.Mex.: School for Advanced Research Press.

Hillenkamp, Isabelle

2013 "Solidarity and Protection in Bolivian Popular Economy." In Securing Livelihoods: Informal Economy Practices and Institutions, edited by Isabelle Hillenkamp, Frédéric

Hummel, Calla Lapeyre, and Andreia Lemaître, 47-63. Oxford: Oxford University Press.

2017 "Disobedient Markets: Street Vendors, Enforcement, and State Intervention in Collective Action." Comparative Political Studies 50, no. 11: 1-32. https://doi. org/10.1177\%2F0010414016679177.

INTA (International Trademark Association)

2015 “Position Paper on Parallel Imports.” New York: INTA. 
Kjellberg, Hans

2007 "The Death of a Salesman? Reconfiguring Economic Exchange in Swedish PostWar Food Distribution.” In Market Devices, edited by Michel Callon, Yuval Millo, and Fabian Muniesa, 65-91. Malden, Mass.: Blackwell.

Lévi-Strauss, Claude

1963 “The Effectiveness of Symbols." In Structural Anthropology, 186-205. New York: Basic Books.

Mangan, Johan, Chandra Lalwani, and Tim Butcher

2008 Global Logistics and Supply Chain Management. Chichester, England: John Wiley and Sons.

Manning, Paul

2010 “The Semiotics of Brand.” Annual Review of Anthropology 39: 33-49. https://doi. org/10.1146/annurev.anthro.012809.104939.

Mazzarella, William

2003 “Very Bombay': Contending with the Global in an Indian Advertising Agency." Cultural Anthropology 18, no. 1: 33-71. https://doi.org/10.1525/can.2003.18.1.33.

Müller, Juliane

2018 "Andean-Pacific Commerce and Credit: Bolivian Traders, Asian Migrant Businesses, and International Manufacturers in the Regional Economy." Journal for Latin American and Caribbean Anthropology 23, no. 1: 18-36. https://doi. $\operatorname{org} / 10.1111 /$ jlca.12328.

Nakassis, Constantine V.

2013 "Brands and Their Surfeits." Cultural Anthropology 28, no. 1: 111-26. https://doi. org/10.1111/j.1548-1360.2012.01176.x.

Ødegaard, Cecilie V.

2008 "Informal Trade, Contrabando and Prosperous Socialities in Arequipa, Peru." Ethnos 73, no. 2: 241-66. https://doi.org/10.1080/00141840802180520.

Roitman, Janet

2004 Fiscal Disobedience: An Anthropology of Economic Regulation in Central Africa. Princeton, N.J.: Princeton University Press.

2007 "The Efficacy of the Economy." African Studies Review 50, no. 2: 155-61. https:// doi.org/10.1353/arw.2007.0122.

Seligmann, Linda J.

1993 "Between Worlds of Exchange: Ethnicity among Peruvian Market Women.” Cultural Anthropology 8, no. 2: 187-213. https://doi.org/10.1525/can.1993.8.2.02a00040.

2004 Peruvian Street Lives: Culture, Power, and Economy among Market Women of Cuzco. Urbana: University of Illinois Press.

Stobart, Henry

2011 "Bolivia." In Media Piracy in Emerging Economies, edited by Joe Karaganis, 327-38. New York: Social Science Research Council.

Tassi, Nico

2010 “The 'Postulate of Abundance': Cholo Market and Religion in La Paz, Bolivia." Social Anthropology 18, no. 2: 191-209. https://doi.org/10.1111/j.1469-8676.2010. 00104.x.

2016 The Native World-System: An Ethnography of Bolivian Aymara Traders in the Global Economy. Oxford: Oxford University Press.

Thomas, Kedron

2013 "Brand 'Piracy' and Postwar Statecraft in Guatemala." Cultural Anthropology 28, no. 1: 144-60. https://doi.org/10.1111/j.1548-1360.2012.01178.x.

2016 Regulating Style: Intellectual Property Law and the Business of Fashion in Guatemala. Berkeley: University of California Press.

Tsing, Anna

2009 "Supply Chains and the Human Condition." Rethinking Marxism: A Journal of Economics, Culture, and Society 21, no. 2: 148-76. https://doi.org/10.1080/ 08935690902743088 . 
2013 "Sorting out Commodities: How Capitalist Value Is Made through Gifts." HAU: Journal of Ethnographic Theory 3, no. 1: 21-43. https://doi.org/10.14318/hau3. 1.003.

UNDP (United Nations Development Programme)

2016 Progreso multidimensional: Bienestar más allá del ingreso. Informe Regional sobre Vann, Elizabeth F. Desarrollo Humano para América Latina y el Caribe. New York: UNDP.

2006 "The Limits of Authenticity in Vietnamese Consumer Markets." American Anthropologist 108, no. 2: 286-96. https://doi.org/10.1525/aa.2006.108.2.286.

Welker, Marina

2018 "The Architecture of Cigarette Circulation: Marketing Work on Indonesia's Retail Infrastructure.” Journal of the Royal Anthropological Institute 24, no. 4: 669-91.

Witzel, Morgen https://doi.org/10.1111/1467-9655.12911.

2002 "A Short History of Efficiency." Business Strategy Review 13, no. 4: 38-47. https:// doi.org/10.1111/1467-8616.00232.

Zoomers, Annelies, and Lee K. Mitzman

1999 Linking Livelihood Strategies to Development: Experiences from the Bolivian Andes. Amsterdam: Royal Tropical Institute / Center for Latin American Research and Documentation. 